\title{
LASTEN JA NUORTEN KUNTOUTUKSEN YHDYSPINNAT
}

Kuntoutus edistää lasten taitoja ja kehitystä yhdessä kasvatuksen, ohjauksen ja opetuksen kanssa. Näiden välillä pyritään nykyisin yhteistyöhön ja synergiaetuun. Sana "yhdyspinnat" kuvaa osapuolten toimintaa uudelta kannalta.

\section{Johdanto}

Tunnettu taulu esittää enkeliä, joka seuraa metsässä kulkevia lapsia. Ohjausta tarvitaan, kaikkea voi sattua. Lapset ovat kuitenkin tavallaan omin neuvoin matkalla. Tässä voidaan nähdä eräänlainen kokonaisajatus tai palvelukokonaisuus, joka tarvitaan turvaamaan parhaat mahdolliset olosuhteet lasten kehitykselle.

Kuntoutuksen tavoitteena on toimintakyvyn kehittäminen ja ylläpitäminen. Lasten kasvatus, ohjaus ja opetus tähtäävät samaan päämäärään, ja toki lapsi kehittää taitojaan itsekin. Otsikon sana "yhdyspinnat" (Heinonen ym. 2018) kuvaa näiden toimintojen keskinäistä suhdetta ja yhdistämistä.

Lapsen kehityksen kannalta perhe on ensisijainen toimija, seuraavina ovat lähiympäristö ja lähi-ihmiset. (Varhais)kasvatus ja kouluopetus ovat tarjolla kaikille lapsille, ketään ei enää suljeta pois niiden piiristä. Sosiaalityö ja kuntoutus tulevat tarvittaessa mukaan tähän kokonaisuuteen.

"Yhdyspinnat" on uusi käsite, joka korostaa eri toimijoiden yhteistyötä. Tämä merkitsee valintoja ja sopimista yksikkörajojen yli, jolloin tämänhetkisen palvelukokonaisuuden ongelmat, sirpaleisuus, arjen vaativuus ja oikeutettujen palvelujen saatavuuden työläys saadaan helpottamaan. Tarvitaan suunnittelua ja kehittämistä, jotta "yhdyspinnat" saadaan toimiviksi ja saumattomiksi (kuvio 1).

Palvelukokonaisuus tulee rakentaa lapsen kehitysympäristöön, mikä merkitsee yhteistä päämäärää ja sen mukaan sovitettavaa toimintaa. Kuntoutumisen taustalla on paljon muutakin kuin kuntoutuksen ammattilaisten palvelut (Sipari \&t Vänskä 2017).

Lähtökohtana kuntoutuksen suunnittelussa ja toteutuksessa on siis lapsi ja perhe. Samalla on huolehdittava, että perheen rasitus ja tehtävät eivät muodostu kohtuuttomiksi. Tämä edellyttää ammattilaisilta osaamista ja asennetta (Sipari ym. 2017). Lapsen ääni on ymmärrettävä myös niin, että yhdeksi osapuoleksi ajatellaan mukaan se aikuinen, joka lapsesta on tulossa.

Saumattoman palvelukokonaisuuden saavuttamiseksi on tärkeää, että kaikki lapsen kanssa työskentelevät ovat selvillä hänen vahvoista ja heikoista ominaisuuksistaan ja tietävät, mitä häneltä voi vaatia, mihin 


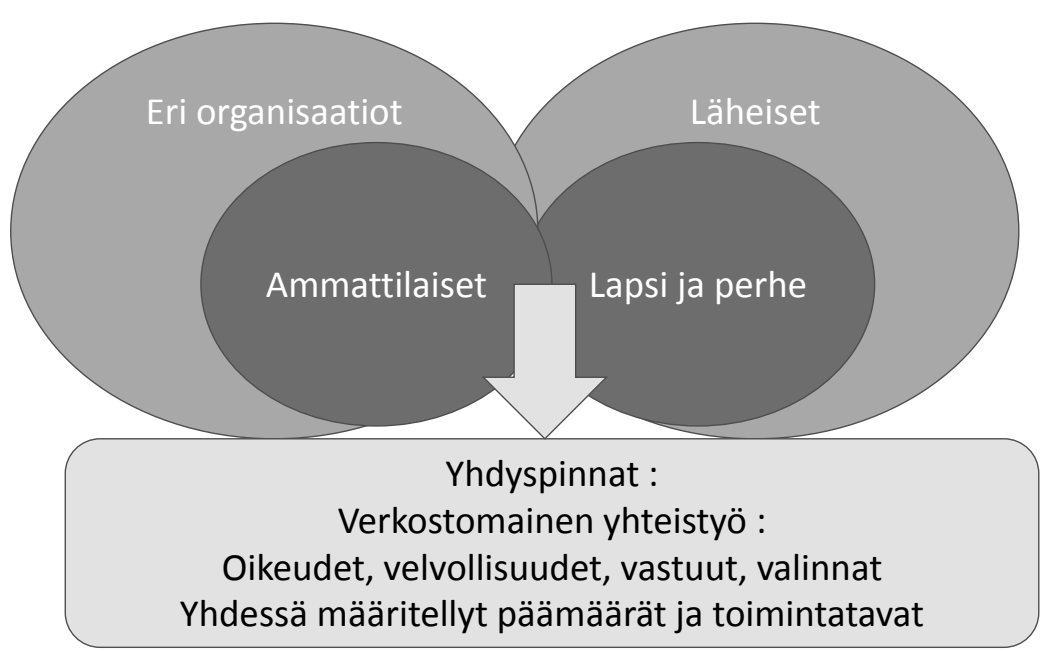

Kuvio 1. Yhdyspinnat kaavamaisesti.

asioihin hänen vuokseen on varauduttava ja millä tavoilla häntä kasvatetaan, ohjataan, opetetaan ja kuntoutetaan.

\section{Tarveryhmät, harkinnanvaraisuus ja yhdyspinnat}

Elämisen tarpeet voidaan jakaa karkeasti kolmeen ryhmään: perustarpeet, osallistuminen ja kasvu. Uusien asioiden oppiminen painottuu viimeiseen ryhmään, entisten taitojen ylläpito keskimmäiseen. Kuntoutuminen liittyy kaikkiin kolmeen, ja tasapainon löytäminen edellyttää suunnittelua ja harkintaa.

Tarveteoreettisessa ajattelussa huomautetaan, varmaan syystä, että painotukset ylikorostavat helposti kasvutarpeiden ryhmää, onhan se luonteeltaan aktiivinen ja vaikuttava. Tätä kautta muun muassa kuntoutukseen kohdistuu myös sellaisia toiveita, joiden täyttäminen olisi parempi hoitaa muuten, perustarpeiden ja osallistumisen alueella (Alderfer 1972). Tätä voi havainnollistaa esimerkein:

- Tehostettukaan opetus tai kuntoutus ei yksin riitä tasapainottamaan arjen vaikeuksia (esteitä tai kynnyksiä liikenteessä, kaupoissa, pankeissa ja niin edelleen, terveydenhuollon jonoista puhumattakaan), vaan näihin on vaikutettava myös suoraan.

- Vaikeavammaisten lasten perheet tarvitsevat ajoittain tai pysyvästi eritasoista, usein vaativaa hoitoapua arjen vaikeuksiin (Hakoma \&t Niemelä 2018). Olosuhteet lapsen arjessa tulee siksi ottaa osaksi asiakassuunnitelmaa, matalan kynnyksen toimintana, perhettä kuunnellen. Tässä on myös selvä yhdyspinta koulun suuntaan, jossa annetaan "elämässä tarpeellisia tietoja ja taitoja" ja "kartutetaan jokapäiväisessä elämässä tarvittavia taitoja" arjen avuksi.

Osallistumisesta voidaan ottaa esimerkiksi lasten liikunta. Kuntoutuksen ja kuntoutumisen kannalta liikunnan merkitys on suuri, mutta silti sen osuus on pikemminkin vähentynyt. Tavallisen arkiliikunnan arvioidaan nykyään olevan liian niukkaa, eikä välituntien raitis ilma ole samassa arvossa kuin ennen. Liikuntaharrastukset ovat puolestaan melko kunnianhimoisia, ja rasitusvammojen yhdeksi syyksi mainitaan kiivaan harjoituksen ja niukan arkiliikunnan epätasapaino.

Tässä lienee tapahtunut liukumaa kasvutarpeiden alueelle, kun harrastusten arvioidaan "kehittävän" vaikkapa aivotoimintaa. Päämäärä on siis muuttunut, osallistuminen ei enää ole pääasia. Vastaavasti liikuntaan katsotaan tarvittavan erityinen paikka, varusteet ja valmentaja, pelkkä liikkuminen tai ulkoilma eivät riitä. Toivotaan "kehitystä", vaikka yhteisöllinen ja osallistava toiminta olisi kukaties tarpeellisempaa ja samalla kyllä kehittävääkin.

Yleisesti ajatellaan, muun muassa ICF:n 
yhteydessä, että osallistuminen on keskeinen asia, mutta samalla sitä käsitellään tavallaan tulevaisuuden päämääränä, vaikka sen pitäisi olla arkipäivää kaiken aikaa - eihän elämää voi odottaa.

Yksi tapa näiden seikkojen kokoamiseen (ja arvostamiseen) on niin sanottu sosiaalinen pääoma, joka ottaa kulttuuriset arvot taloudellisten oheen ja muodostaa niistä sosiaalisen mallin. Yhteisöllisyys rakentuu sosiaalisen pääoman kautta ja ilmenee toimintana yhteiseksi hyväksi (Pinxten \&t Lievens 2014). Kaikki nämä seikat vaikuttavat koettuun hyvinvointiin (Hirvilammi 2015). Tämän saavuttaminen edellyttää organisointia ja johtamista (Barabasi \&t Frangos 2002).

Tarveharkintaan kuuluu myös rajaus. Kehitysympäristön mahdollisuudet eivät ole automaattisesti aina tarpeellisia (Pelkonen 2019). Koulu on onnistunut luomaan lukujärjestyksen, joka rajoittaa kunkin kouluaineen kohtuuteen. Tämä on tavoitteena myös kuntoutuksen sovittamisessa kehitysympäristön kokonaisuuteen.

\section{Yksilölliset tarpeet}

Yksi parhaista tavoista yksilöllisen kehityksen hahmottamiseksi ja kuntoutustarpeen arvioimiseksi lienee seuraava kolmiportainen malli (Vygotsky 1978): Lapsi osaa jo jotain (1), on juuri oppimassa jotain tai osaa sen ohjattuna (2), kun taas osa asioista on vielä kehitys- ja oppimismahdollisuuksien ulkopuolella (3).

1) Ensimmäinen "porras" käsittää ne taidot, jotka ovat lapsen hallussa aina, ympäristöstä tai ohjauksesta riippumatta. Tämä on se osaaminen, jota testeillä ja tutkimuksilla ensisijaisesti mitataan, siitä huolimatta, että lapsi vain harvoin toimii yksin. Kuntoutuksen kannalta kyseessä on olemassaolevan toimintakyvyn ylläpitäminen.

2) Keskimmäinen "porras" on se yksilöllinen alue, jonka puitteissa lapsi oppii uutta vuorovaikutuksessa ympäristön kanssa. Se on olemassa kaikilla lapsilla. Tämän alueen sisältö ja laajuus (rajat) ovat kun- toutuksen kannalta keskeisiä asioita, ja etenkin sen yläraja on kuntoutuksen rajaamisen kannalta olennainen. Arviointi ei ole mahdollista kertatutkimuksella, vaan sitä tehdään kuntoutuskertojen yhteydessä (palautteet).

3) Kolmas "porras" on alue, johon lapsen kehitys ei anna (vielä) mahdollisuuksia. Hän ehkä pystyy tämän asteisiin suorituksiin vahvasti "tuettuna", mutta toiminta on silloin passiivista ja virheellisesti fasilitoitua eikä se enää edusta omaa suoritusta tai edistä kehitystä.

Sama ajattelu sopii moneen muuhunkin asiaan, joiden kohdalla on arvioitava, mikä on mahdollista ja mikä ei, esimerkkeinä valinnat itsemääräämisessä, koulutuksessa, työelämässä ja asumisessa. On epäiltävissä, että hyvää tarkoittavien pyrkimysten yhteydessä mahdollisuuksien rajoja ylitetään, jolloin oma suoritus ei lisäänny, stressi ja ahdistus sen sijaan kyllä.

Nämä lapsen kasvuun ja kehitykseen liittyvät seikat eivät yksin riitä kuntoutustarpeen määrittämiseen, koska vuorovaikutuksen osuus on olennainen lapsen kaikessa toiminnassa. Ympäristön ominaisuudet ovat siten yhtä tärkeät kuin yksilön, ja yllä mainitut "portaat" määräytyvät myös niiden mukaan.

Kasvu ja kehitys tapahtuvat vuorovaikutuksessa seuraavien tekijöiden kanssa:

- esimerkkiä antava ryhmä (osallisuus),

- pidemmälle ehtinyt vertaisoppija ja

- ohjaava aikuinen.

Kunkin osuus vaihtelee sen mukaan, miten muut toimivat. Lähiympäristön monet mahdollisuudet ja toimintavaihtoehdot tulevat tässä esiin. Tämä seikka voi näyttää jopa eriarvoisuudelta, mutta antaa itse asiassa väljyyttä paikallisille ratkaisuille (Brax 2018).

Tämä puhuu voimakkaasti yksilöllisyyden ja yhteisöllisyyden puolesta. Kukin lapsi on yksilö ja jokainen ympäristö on yksilöllinen. Yhdyspintojen luoma kokonaisuus muodostetaan niistä asioista, jotka parhaiten edistävät lapsen kehitystä. Voidaan ajatella, että kuntoutustarpeen yksilölliseen vaihteluun voidaan vastata asiakaslähtöisyyden 
avulla paremmin kuin muuten (Jepperson 1991).

Kuntoutus ei kohdistu diagnoosipohjaisiin vajavuuksiin ja häiriöihin vaan lapsen mahdollisuuksiin, siihen, mitä on olemassa. Jos lapsi ja perhe nostetaan ensisijaiseen asemaan, päämääriksi muodostuvat yksilöllinen kuntoutuminen, oppiminen ja kehittyminen, ja koko asetelma selvenee.

\section{Saumaton palvelukokonaisuus}

Sosiaali- ja terveysministeriön muistio "Kuntoutuksen uudistamiskomitean ehdotukset kuntoutusjärjestelmän uudistamiseksi” (STM 2017) pyrki poistamaan nykyjärjestelmän hajanaisuutta ja täsmentämään eri osatekijöiden tehtäviä ja yhteistyötä. Tätä kuvaa ehkä parhaiten käsite "verkostomainen yhteistyö".

Myös LaPe/OT-, VIP- ja LOOK-hankkeet, erityishuoltopiirien selvitykset, kuntien hyvinvointi- ja hyte-suunnitelmat, varhaiskasvatuksen ja koulun uudistukset, kolmannen sektorin moninaiset hankkeet ja niin edelleen pyrkivät vastaavantyyppiseen toimintakokonaisuuteen. Verkostomaisen yhteistyön kautta saavutetaan yhteinen ymmärrys toiminnan tarkoituksesta (tavoite, miksi) ja yhteinen suunnitelma toimintatavasta (mitä, miten, milloin, missä ja kuka).

Uhkakuvana on kuitenkin se, että tämäntapainen toimintamalli ei ole (vielä) kenenkään vastuulla. Markkinavoimien hallinta (kilpailutus, koordinoimattomat sopimukset) on hajanaista ja kohdistuu ensisijaisesti rajaamiseen, jolloin hankintojen pitkäjänteisyys, laatu, saatavuus ja jatkuvuus saavat liian vähän huomiota. Suunnittelu on kuitenkin meneillään. Suuri paino asetetaan kehitteillä oleviin osaamis- ja tukikeskuksiin (OT-keskuksiin) (Halila ym. 2019), joiden etäisyys lasten ja perheiden arjesta vaikuttaa kuitenkin huolestuttavan suurelta.

Työ toteutetaan lähiympäristössä eri tahojen yhteistyönä (Hakoma \&t Niemelä 2018), jolloin yhteisöllisyys, inkluusio ja monitasoinen integraatio ovat keskeisiä päämääriä. Samalla tulee varmistaa lapsen ja perheen osallisuus (Sipari ym. 2017).

Palvelukokonaisuuden toimivuus voi- daan ryhmittää kolmeen osaan:

1) saatavuus (palvelukokonaisuuden lukuisat osatekijät ovat olemassa)

2) saavutettavuus (jonot $\leftrightarrow$ yhteisön palvelu- ja vastaanottokyky)

3) sujuvuus (yhteistyö $\leftrightarrow$ palvelut ihmiseltä ihmiselle).

Nämä kolme asiaa muodostavat kriteerit tai mittarit palvelukokonaisuuden toimivuuden arvioimiseksi. Niiden puutteellinen toteutuminen aiheuttaa heikkojen tulosten lisäksi palvelujen sirpaleisuuden ja sen kautta perheille vaativan arjen. Sujuvuus (= palvelujen mutkaton järjestyminen) on parhaiten saavutettavissa lähiympäristöä korostamalla. Vaikka kuntoutustoimet edellyttävät erityisosaamista, niiden yhteydessä voidaan silti toimia luontevasti, ilman jonoja ja anomisia.

Yllä esitetty "ihmiseltä ihmiselle" -ajatus tarkoittaa sitä, että asiaa hoitava ihminen pystyy ammattitaitonsa avulla tekemään järjestelyt toisen ihmisen avuksi sellaisessa muodossa, että se aidosti, suoraan ja ilman viiveitä palvelee tämän asiaa.

Tämän mahdollisuuden aikaansaamiseksi verkosto tarvitsee selvän ohjauksen, niin sanotun prosessivastuutahon (STM 2017), jolla on oltava tietyt valtuudet. Tämän tahon on huolehdittava tarpeiden tunnistamisesta, palvelukokonaisuuksien määrittelemisestä ja tiedon hyödyntämisestä eri osapuolten välillä. Hankintojen johtaminen käsittää puolestaan sekä saatavuuden varmistamisen että budjetissa pysymisen (Iloranta \& Pajunen-Muhonen 2018). Nämä seikat ovat muun suunnittelun ja toteutuksen perusta.

Lapsen ja perheen tarpeiden perusteella muodostetaan erilaisista osatekijöistä kokonaisuus, joka voidaan nähdä kahden risteävän "akselin" kohtaamisena:

1) toiminnan kannalta "tarpeesta toteutukseen"-akseli (näin toimitaan)

2) taloudelliselta kannalta "sisällön avulla vaikutukseen" -akseli (nämä ovat keinot). Hankintoihin liittyy kilpailutus, jolloin kriteerit jaotellaan yleensä taloudellisiin ja laadullisiin. Ei ole kuitenkaan selvää, että juuri nämä perusteet riittävät takaamaan riittävän monipuolisen hankinnan. Halvin hinta on helppo havaita, mutta "laatua" on vaikea määritellä niin, että valikoima pys- 
tytään hankkimaan yksilöllisten tarpeiden mukaisesti.

"Tarpeesta toteutukseen" ei voida edetä myöskään niin, että vaihtoehtoja on vapaasti valittavissa ja laadun takaava tulos määräytyy markkinavoimien mukaan. Tällaista mahdollisuutta kaavaillaan terveydenhuoltoon ja monin paikoin sille onkin käyttöä, mutta vaativien tehtävien kohdalla toteutus edellyttää niin ammattitaitoista toimintaa (ja valintoja sen piirissä), että yleensä on olemassa vain yksi toimija, joka tähän pystyy.

Jotta päästäisiin parhaaseen mahdolliseen vaikutukseen, saatavana tulee olla tuo yksilöllisten tarpeiden edellyttämä valikoima sisältöä. Tällaisen aikaansaaminen edellyttää, että tarkastellaan monipuolisesti asioiden referenssejä, vahvuuksia ja heikkouksia, osaamisia ja asiakkaiden kokemuksia. On laadittava tarjouspyyntöjä, jotka hyödyntävät laajalti aikaisempaa tietoa ja joissa kattavat ja pitkän aikavälin vaikutukset ja niiden vastaavuus tarpeiden kanssa muodostavat painopisteen.

Näillä periaatteilla voidaan hankinnoissa saavuttaa sellainen kokonaisuus, joka kattaa tarpeet sekä laadukkaasti että riittävän yksilöllisesti. "Laatu" on siis nähtävä varsin monipuolisena asiana.

Käytössä on nykyään tarpeiden ja keinojen normittaminen diagnoosien, laillistamisen tai muiden sellaisten käsitteiden avulla. Näin täytyy menetellä, mutta normien ja nimikkeiden taustalla on säilytettävä yksilöllisyys ja yhteisöllisyys. Lapsi ei saa muuttua diagnoosikseen eikä kuntoutus kappaletavaraksi, vaikka liike-elämän malleissa helposti näin onkin.

Vaikutukseen liittyy vaikuttavuuden käsite. Kuntoutusmenetelmien vaikuttavuustutkimukset ovat pääsääntöisesti hyvin tuoreita, ja lyhyehköjen interventioiden antamat tulokset ovat myös kiistanalaisia. Kouluopetuksen tehoa on tutkittu kauemmin, mutta menetelmien paremmuudesta ja annostelusta vallitsee sielläkin samankaltainen mielipiteiden kirjo (Mortimore ym. 1988). Kuntoutuksen voidaan olettaa vaikuttavan parhaalla tavalla, kun lähiverkosto on mukana palvelukokonaisuudessa sen suunnitelmallisena osana (kuvio 2).

Toistaiseksi ei vaikuttavuuden arvioinnissa voitane soveltaa kaavamaista ajattelua, vaan moni asia joudutaan jättämään harkinnanvaraiseksi. Tämä tarkoittaa sitä, että valinnoissa otetaan huomioon kaikki mahdollinen teoreettinen ja kokemusperäinen tieto mutta tunnistetaan samalla tämän tiedon rajallisuus ilmiöiden ja syysuhteiden selittäjänä.

\section{Kuntoutus ja saumaton palvelukokonaisuus}

Palvelukokonaisuudessa järjestäjä näkee oman tehtävänsä, perhe taas sen elämään kohdistuvat useat toiminnat. Nämä tulisi saada yhdistettyä. Asiaa voidaan hahmottaa kolmena toimintalinjana (akselina), jotka yhdessä antavat ulottuvuudet ja yhdyspinnat verkostomaiselle yhteistyölle:

1) Hallinnollinen akseli - palvelujen järjestäminen lapsen ja perheen lähelle

2) Organisaatioiden välinen akseli - yhteis-

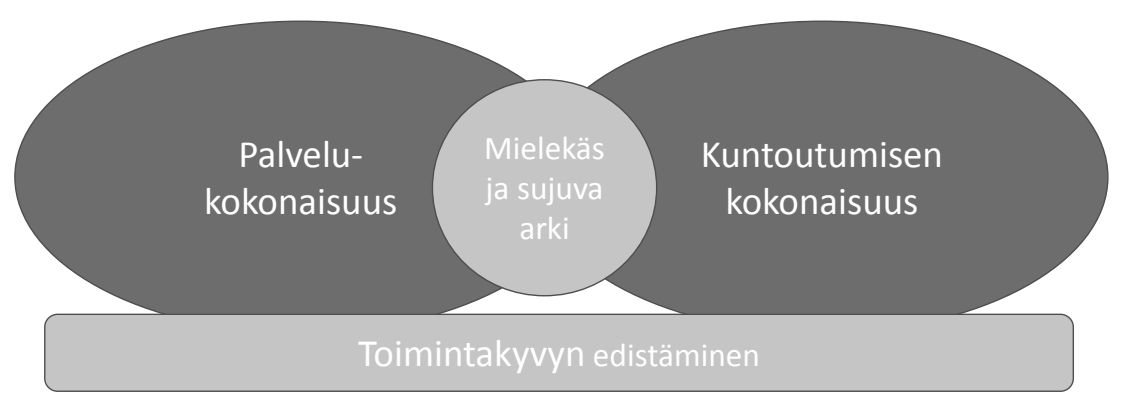

Kuvio 2. Palvelujen ja kuntoutumisen suhde. 
työ lähiympäristössä

3) Translationaalinen akseli - teorioiden siirtäminen käytäntöön.

Kokonaisuus on siis kolmiulotteinen, nykykielellä 3D. Se on huomioitava "laidoille asti”, toisin sanoen mikään asia ei saa jäädä erilliseksi, rajatuksi tai muuten irralliseksi osaseksi (sirpaleeksi).

Malli korostaa sitä, että kuntoutus ei ole pelkästään palvelupolku ylhäältä alas (1), vaan palvelut lähiympäristössä edellyttävät horisontaalista yhteistyötä (2) ja toimintaan liittyy aina sekä teoria että käytäntö (3) (translationaalinen kuntoutus, ks. Aldeguer ym. 2016).

Nämä asiat kootaan alustavasti kuntoutussuunnitelmaan, ja varsinainen palvelukokonaisuus yhdyspintoineen syntyy lähiympäristössä asiakassuunnitelman kautta. Tällä hetkellä on totuttu laajentamaan paikallista palveluvalikoimaa tukeutumalla erikoissairaanhoitoon, ja lähiympäristön mahdollisuuksia saatetaan jopa väheksyä. On selvää, että tämä aiheuttaa sirpaleisuutta ja eriasteisia viiveitä.

Kuntien hyvinvointisuunnitelmien perusteella voi hahmottaa mahdollisuuksia. Ne sisältävät paljon asioita ja tuovat esiin kuntien yksilöllisyyttä. Puutteita ehkä on, mutta kehittämistyö on meneillään. Kuntien tulisi tässä olla vastaanottavaisempia kolmannen sektorin esittämien mallien suhteen. On arvioitavissa, että muuten syntyy merkittäviä tyhjään päättyviä kustannuksia, kun kolmannen sektorin alullepanema asia ensin suunnitellaan, sitten esitellään ja lopuksi hylätään (Brax 2018).

Pitäisi päästä siihen, että kunta havaitsee itse puutteensa, analysoi tilanteen ja tilaa sitten tarvittavan palvelun vaikkapa kolmannelta sektorilta. Olisi tärkeää, että OT-keskukset kannustaisivat kuntia toimimaan näin ja ohjaisivat käytännön toteutusta. Kuntoutusohjaus on tässä luonteva kanava.

Nykyään korostetaan kuntoutumista, ja sen kannalta nykyinen erillisyys (sirpaleisuus) on haitta. Verkostomainen yhteistyö pyrkii kokonaisratkaisuun, jossa saavutetaan tietty synergiaetu ja helpotetaan perheiden arkea. On mietittävä, mitä siihen kuuluu ja miten "saumaton palvelukokonaisuus" voidaan kaikkien eduksi saavuttaa.

\section{Matti Koivikko, lääkintöneuvos, lasten- neurologian dosentti, TaY}

\section{Salla Sipari, FT, yliopettaja, Metropolia}

Kirjoitus perustuu Valtakunnallinen Lasten ja Nuorten Kuntoutus ry:n (VLK) verkkojulkaisuun: Lasten ja nuorten hyvä kuntoutus alueellinen järjestäminen, 2019, http://www. vlkunto.fi

\section{Lähteet}

Aldeguer JS ym. (2016) Evidence-based physiotherapy and translational research. Physiotherapy Updates 12, 73-77.

Alderfer CP (1972) Existence, relatedness, and growth. Human needs in organizational settings. New York, Free Press.

Barabasi A, Frangos J (2002) Linkit: verkostojen uusi teoria. Terra Cognita. (Suom. Kimmo Pietiläinen.)

Brax T (2018) Järjestöjen rooli maakunta- ja sote-uudistuksessa. Selvityshenkilön raportti. Sosiaali- ja terveysministeriön raportteja ja muistioita 26. STM, Helsinki.

Hakoma R, Niemelä M (2018) Erityishuoltopiirit poistuvat, työ ja palvelu jatkuvat. Selvityshenkilöraportti erityishuoltopiirien asemasta sosiaali- ja terveydenhuollon uudistuksessa. Sosiaali- ja terveysministeriön raportteja ja muistioita 42. STM, Helsinki.

Halila R, Kaukonen P, Malja M, Savola S (2019) Lasten, nuorten ja perheiden osaamis- ja tukikeskukset. LAPE-muutosohjelmassa tehdyn valmistelutyön loppuraportti. Sosiaali- ja terveysministeriön raportteja ja muistioita 30. STM, Helsinki.

Heinonen O-P ym. (2018) Yhdyspinnat yhteiseksi mahdollisuudeksi. Selvitys lapsi-, nuoriso- ja perhepalveluiden toteuttamiseen liittyvistä yhdyspinnoista muuttuvassa toimintaympäristössä. Sosiaali- ja terveysministeriön raportteja ja muistioita 8. STM, Helsinki.

Hirvilammi T (2015) Kestävän hyvinvoinnin jäljillä. Ekologisten kysymysten integroiminen hyvinvointitutkimukseen. Sosiaali- ja terveysturvan tutkimuksia 136. Kela, Helsinki.

Iloranta K, Pajunen-Muhonen H (2018) Hankintojen johtaminen: Ostamisesta toimittajamarkkinoiden hallintaan. Tietosanoma. (5. painos.)

Jepperson RL (1991) Institutions, institutional effects, and institutionalism. Kirjassa WW Powell, PJ DiMaggio (toim.) The new institutionalism in organizational analysis. University of Chicago Press.

Mortimore P ym. (1988) School Matters. The Junior Years. Open Books.

Pelkonen R (2019) Oppia ikä kaikki. Suomen Lääkärilehti 74, 5.

Pinxten W, Lievens J (2014) The importance of economic, social and cultural capital in understand- 
ing health inequalities: using a Bourdieu-based approach in research on physical and mental health perceptions. Sociology of Health \& Illness 36, 7, 1095-1110.

Sipari S, Vänskä N (2017) Käsikirja - Osallistumisen ekologinen arviointi: Yhteinen arviointi ja suunnittelu lapsen osallistumiseksi merkitykselliseen toimintaan. Metropolia Ammattikorkeakoulun julkaisuja.

Sipari S, Vänskä N, Pollari K (2017) Lapsen edun toteutuminen kuntoutuksessa. Osallistumista ja toimijuutta vahvistavat hyvät käytännöt. Sosiaali- ja terveysturvan raportteja 5. Kela, Helsinki.

STM (2017) Kuntoutuksen uudistamiskomitean ehdotukset kuntoutusjärjestelmän uudistamiseksi. Sosiaali- ja terveysministeriön raportteja ja muistioita 41. STM, Helsinki.

Vygotsky L (Cole M ym. toim.) (1978) Mind in society: the development of higher psychological processes. Cambridge, Harvard University Press. 